\title{
Rola pracy i nauczania w koncepcji wychowania integralnego Edmunda Bojanowskiego na tle europejskich prądów wychowawczych XIX wieku
}

$D^{2}$ zieciństwo, w sensie wyodrębnionego okresu życia człowieka, ma w Europie relatywnie krótką historię. Jego powstanie wiąże się z rozwojem społeczeństwa obywatelskiego oraz zbioru zasad niezbędnych do życia i funkcjonowania państwa, a więc sytuuje się w XVII wieku. Przemiany polityczno-gospodarcze stawiają społeczeństwo przed nowego rodzaju zadaniem, mianowicie przekazania poprzez właściwe instytucje nowonarodzonym obywatelom potrzebnej do życia wiedzy. Powstaje system szkolny, obejmujący wszystkich obywateli. Obok rozwoju systemu szkolnego trzeba wymienić rozbudowę innych zinstytucjonalizowanych form wychowania i spędzania wolnego czasu. Zainteresowanie wychowaniem małego dziecka w Polsce zaznacza się wyraźnie w XIX wieku. Do pionierów w tej dziedzinie zaliczamy Augusta Cieszkowskiego, Ewarysta Estkowskiego i Edmunda Bojanowskiego. Ostatni z wymienionych położył największy akcent na praktyczne organizowanie opieki nad małym dzieckiem. Zarys dwóch kluczowych kierunków w pedagogice europejskiej XIX wieku będzie tłem, na którym zostanie zaprezentowana oryginalna koncepcja wychowania integralnego bł. Edmunda Bojanowskiego. J. H. Pestalozzi i J.F. Herbart zostali wybrani do tej prezentacji także dlatego, że autor znalazł w ich myśli pedagogicznej linie styczne do koncepcji wychowawczych wielkopolskiego Pedagoga.

\footnotetext{
* Ks. DR JACEK ZJawin - adiunkt w Zakładzie Katechetyki i Pedagogiki Chrześcijańskiej, Wydział Teologiczny Uniwersytetu im. Adama Mickiewicza w Poznaniu. E-mail: jz@amu.edu.pl.
} 


\section{Domy pracy manualnej Pestalozziego}

Johann Heinrich Pestalozzi urodził się jako jedno z siedmiorga dzieci w rodzinie kupieckiej 12 stycznia 1746 roku w Zurychu. Doświadczenia życiowe istotnie wpłynęły na jego koncepcje pedagogiczne. Czwórka rodzeństwa i ojciec zmarli, zanim Johann osiągnął wiek pięciu lat, co znacznie pogorszyło, już i tak trudną sytuację materialną rodziny Pestalozzi. Wychowywany początkowo przez kobiety (najpierw nadopiekuńcza matka, a potem żona, która przejęła rolę matki), a następnie korzystając $\mathrm{z}$ darmowego szkolnictwa, szybko stał się studentem prawa i w końcu dobrze wykształconym obywatelem miasta Zurich. Powodowany doświadczeniem zetknięcia z niewyedukowanym ludem wiejskim, w wieku 21 lat porzucił studia i został rolnikiem, z intencją edukowania środowiska wiejskiego. Pragnienie osiągnięcia niezależności finansowej i założenia rodziny wpędziło go w poważne tarapaty finansowe i rozpaczliwe próby wyjścia z długów ${ }^{1}$. W latach 1774-1780 w swojej posiadłości założył zakład dla bezdomnych dzieci z okolicy. Troska, której doświadczył w dzieciństwie, stała się istotnym elementem jego systemu wychowawczego. Swoich podopiecznych karmił, ubierał, pokazywał jak pracować, uczył i wychowywał. Nie był w swojej działalności zupełnie bezinteresowny, gdyż jego upadające gospodarstwo miało być utrzymywane z pracy dzieci na roli, w ogrodzie, warsztatach tkackich i farbiarniach. Ten projekt $w$ wymiarze finansowym poniósł fiasko, jednak pewne spostrzeżenia i refleksje mocno zapadły mu w pamięć. Do końca życia nosił w sobie tęsknotę do bycia figurą ojca pośród swoich biednych dzieci, wiedząc z własnego doświadczenia, jak bardzo brak ojca utrudnia właściwe wychowanie.

Działalność wychowawcza domu dla biednych Pestalozziego stała się początkiem nowej koncepcji pedagogicznej. Podczas pracy wychowankowie uczyli się tam czytania, pisania oraz geografii. Szkoła i wychowanie szkolne miały być narzędziem odrodzenia społecznego. Celem wychowania według Pestalozziego było rozwinięcie tego, co się znajduje w człowieku. W takim ujęciu widać było silne wpływy poglądów J.J. Rousseau, z którego filozofią Johann zetknął się jeszcze jako student. Według Pestalozziego szkoła miała być miejscem sprzyjającym szkoleniu predyspozycji człowieka, a nie wypełniać go niedostosowaną do potrzeb wiedzą. Predyspozycje według niego rozwijają się przez ich używanie, a nieaktywizowane zanikają. Zadaniem nauczyciela było pozwolić obserwować i badać, zachęcać do kreatywności i wychodzić naprzeciw potrzebom wychowanka. Predyspozycje i zdolności człowieka dzielił na trzy siły: intelektualną - związaną z myśleniem (postrzeganie, pamięć, wyobraźnia, bogactwo języka, prowadzące do zrozumienia świata, określenia przyczyny

${ }^{1}$ Por. G. Kuhlemann, Childhood and Youth in Zurich, http://www.en.heinrich-pestalozzi.de/ biography/childhood-and-youth-in-zurich/, tł. wł., [dostęp: 24.11.2016]. 
rzeczy), moralną (miłość, wiara, zaufanie, wdzięczność, sumienie, przeczuwanie, wartościowanie), fizyczną (związaną z wolą i działaniem siły manualnej). Uważał, że każdą z tych sił należy maksymalnie rozwijać, najlepiej we wspólnej harmonii ${ }^{2}$. Charakterystyczne dla Pestalozziego było mówienie o „mocach serca", które człowiek odkrywa poprzez rozwijanie zdolności intelektualnych i manualnych (head and hand - głowa i ręka). Wychowanie według niego miało ożywiać pozytywne uczucia, zaufanie do innych oraz posłuszeństwo sumieniu i uwielbienie Stwórcy ${ }^{3}$. Jego teoretyczne rozważania o wychowaniu znalazły swoje odzwierciedlenie w eksperymentalnych szkołach i zakładach wychowawczych, które niestrudzenie zakładał. Zmarł 17 lutego 1827 roku w Brugg, do ostatnich chwil walcząc o realizację swoich idei wychowawczych w praktyce.

\section{Nauczanie wychowujące Herbarta}

U podstaw współczesnej pedagogiki leżą teorie, które stworzył 200 lat temu Johann Friedrich Herbart. Urodził się 4 maja 1776 roku w Oldenburgu (Niemcy), zmarł 14 sierpnia 1841 roku w Getyndze. Od dziecka wykazywał się talentem filozoficznym, był pod wpływem filozofii K. Wolfa i I. Kanta. W dzieciństwie uległ poważnemu wypadkowi, który uniemożliwił mu uczęszczanie do publicznej szkoły. Jego pierwszą i przez wiele lat jedyną nauczycielką była matka ucząca Johanna w domu, a potem towarzysząca mu w podróży do miasta Jena, gdzie został studentem i wszedł do kręgu uczniów wybitnego filozofa klasycznego idealizmu, J. G. Fichtego. Będąc prywatnym nauczycielem w szwajcarskiej rodzinie, spotkał Pestalozziego i to właśnie pod jego wpływem zainteresował się pedagogiką ${ }^{4}$. Najbardziej inspirujące były poglądy Pestalozziego krytykujące dotychczasowy system edukacyjny i akcentujące odkrywanie autonomii ucznia w procesie nauczania. Herbart rozwiązał dylemat Pestalozziego, który wahał się między pedagogiką rozumianą jako sztuka, a pedagogiką, w której istotą jest metoda, opowiadając się za drugim punktem widzenia. Psychologicznie interpretowana koncepcja natury, różniła teorię Herbarta od Stanowiska Rousseau i Pestalozziego ${ }^{5}$. W kolejnych latach poszukiwania edukacyjne Herbarta zawiodły go do Getyngi, gdzie obronił doktorat i habilitację. W 1806 r., kiedy Getynga dostała się pod francuską okupację przejął katedrę filozofii w Królewcu po Immanuelu Kancie. W 1833 r. powrócił do Getyngi.

${ }^{2}$ Por. M. Gigilewicz, Pestalozzi, w: (red.) E. Gigilewicz, Encyklopedia Katolicka, T. XV, Lublin 2011, kol. 371.

${ }^{3}$ Por. Tamże.

${ }^{4}$ Por. K. Alana, Johann Friedrich Herbart, http://plato.stanford.edu/entries/johannherbart/\#BioSke, tł. wł. [dostęp: 25.11.2016].

${ }^{5}$ Por. B. Śliwerski, Pedagogika. Podstawy nauk o wychowaniu, Gdańsk 2014, s. 65n. 
Herbart stworzył podstawy naukowego statusu pedagogiki, opierając się na kantowskim założeniu, że etyka wyznacza, uzasadnia i pozwala określić cel wychowania. Według Herbarta, głównym celem wychowania było ukształtowanie moralnego charakteru, które można osiągnąć za pomocą wyrobienia karności i nauczania wychowującego, dającego wiedzę i budującego charakter ${ }^{6}$. Twórca szkoły tradycyjnej w ogóle nie doceniał czynności uczniów, czyli ich uczenia się. Najmocniej natomiast podkreślał karność uczniów, którą silnie powiązał z nauczaniem kierowanym przez nauczyciela, według następujących stopni formalnych: jasność, kojarzenie, system i metoda. W. Rein rozszerzył stopnie formalne nauczania do pięciu: przygotowanie, podanie, powiązanie, zebranie, zastosowanie ${ }^{7}$. Metoda ta w szkolnym nauczaniu była głównym elementem metodyki do końca XX wieku. Współczesne badania nad twórczością J.F. Herbarta ukazują niekompletną i tendencyjną recepcję jego idei pedagogicznych. Głównym powodem wielu nieporozumień było oddzielenie jego pedagogiki od jego filozofii ${ }^{8}$. Nie da się jednak cofnąć pewnych procesów, które ta recepcja rozpoczęła i które kształtują specyfikę relacji pomiędzy wychowaniem, a nauczaniem po dziś dzień. Warto jeszcze dodać, że krytyka szkoły tradycyjnej doprowadziła w końcu XIX i w XX wieku do powstania różnych koncepcji i kierunków w teorii i metodyce edukacji. Najważniejsze z nich to szkoła pracy, czyli uczenie się przez działanie. Propagatorami takiej koncepcji byli J. Dewey i G. Kerschenszteiner'. Pomimo pewnego regresu w okresie międzywojennym system herbartowski powrócił w Rosji Sowieckiej już w 1928 roku, a po II Wojnie Światowej został narzucony państwom obozu socjalistycznego. Jego pozostałości: encyklopedyzm, intelektualizm i racjonalizm w kształceniu oraz system klasowo-lekcyjny w organizacji oświaty nadal stanowią składnik polskiego systemu oświatowego ${ }^{10}$.

\section{Wychowanie integralne według Edmunda Bojanowskiego}

W nakreślonym kontekście pedagogicznym, w realiach polskich dodatkowo jeszcze naznaczonym trwaniem zaborów, idee wychowawcze bł. Edmunda Bojanowskiego wydawały się iść z duchem czasu. Bojanowski urodził się 14 listo-

${ }^{6}$ Por. M. Marczewski, Herbart Johann Friedrich, w: Słownik katechetyczny, (red.) J. Gevaert, K. Misiaszek, Warszawa 2007, s. 295n.; J. Walkusz, Herbart, w: (red.) E. Gigilewicz, Encyklopedia Katolicka, T. VI, Lublin 1993, kol. 738.

${ }^{7}$ Por. J. Kujawiński, Ewolucja szkoły i jej współczesna wizja, Poznań 2010, s. 12.

${ }^{8}$ Por. J. Gara, Specyfika polskiej recepcji twórczości Johanna Friedricha Herbarta, w: „Przegląd Pedagogiczny", T. 2 (2012), s. 22-32.

9 Tamże.

${ }^{10}$ Por. B. Śliwerski, dz. cyt., s. 67. 
pada 1814 roku w Grabonogu, a zmarł 7 sierpnia 1871 roku w Górce Duchownej. Jego życie z małymi wyjątkami studenckich podróży, upłynęło w granicach dzisiejszej Wielkopolski ${ }^{11}$. Około roku 1819, 5-letni Edmund doznał cudownego uzdrowienia w sanktuarium na Świętej Górze w Gostyniu. Ze względu na słaby stan zdrowia nie uczęszczał do szkoły publicznej, ale uczył się w domu pod kierunkiem ks. Jana Siwickiego - wikariusza z pobliskiej parafii. Mając 18 lat, wyjechał na studia filozoficzne do Wrocławia, a następnie do Berlina. Studia przerwał z powodu rozwijającej się gruźlicy. Powrócił do Grabonoga, gdzie oddał się całkowicie pracy społeczno-charytatywnej i wychowawczej. W 1884 r. był współzałożycielem pierwszej ochronki w Poznaniu, a w 1885 r. w Gostyniu. W wychowaniu sierot Bojanowski kładł nacisk na elementy religijne i przyzwyczajanie do pracy fizycznej. Aby zdobyć środki na utrzymanie ochronek, najpierw korzystał z odziedziczonego majątku, a potem wydawał czasopismo „Pokłosie. Zbieranka literacka na rzecz sierot”"12. Publikował w nim teksty literackie tworzone nieodpłatnie przez pisarzy, z którymi utrzymywał przyjacielskie kontakty. „Pokłosie” było także miejscem prezentowania jego osobistej twórczości literackiej.

Błogosławiony Edmund Bojanowski był, jako osoba świecka, założycielem Zgromadzenia Sióstr Służebniczek Najświętszej Maryi Panny, co wówczas budziło wiele kontrowersji i niezrozumienia. Pomysł stworzenia zgromadzenia powstał, gdy Edmund zauważył, że opiekunki w ochronkach potrzebują głębszej formacji intelektualnej i duchowej. W swoich notatkach szczegółowo opisał rozmaite cechy charakteru, życia duchowego, a nawet pochodzenie, wiek i urodę, jaką miały się odznaczać „ochroniarki”" zainspirowana troską o zaniedbane dzieci wiejskie, których liczba nieustannie się zwiększała, także z powodu epidemii cholery i innych chorób zakaźnych, nawiedzających ziemie polskie, pozostające pod okupacją zaborców. Swoje poglądy wychowawcze, przepojone głębokimi wartościami chrześcijańskimi, Bojanowski oparł na zasadach wyniesionych $\mathrm{z}$ domu rodzinnego, zdobytej wiedzy oraz własnych, wnikliwych obserwacjach. Był wyjątkowo dobrze przygotowany pod względem intelektualnym, moralnym i duchowym do kreowania nowej koncepcji wychowania ${ }^{14}$. Wcześniej zapoznał się z systemem wychowawczym

${ }^{11}$ R. Kisiel, Błogosławiony Edmund Bojanowski i jego idea wychowania religijnego, Materiały z Sympozjum: Aktualność idei pedagogicznych błogosławionego Edmunda Bojanowskiego i ich implikacje katechetyczne, Poznań, 2012, s. 15-20.

${ }_{12}$ M. Kornacka, Bojanowski Edmund, w: (red.) F. Gryglewicz, Encyklopedia Katolicka, Lublin 1976, kol. 738-739.

${ }_{13}$ Por. M. L. Opiela, Kompendium edukacyjne Edmunda Bojanowskiego, Lublin 2016, s. 181.

${ }_{14}$ Por. A. Maj, Współczesny kontekst katechetyczny idei pedagogicznych błogosławionego Edmunda Bojanowskiego, materiały z sympozjum, w: Aktualność idei pedagogicznych błogosławionego Edmunda Bojanowskiego i ich implikacje katechetyczne, Poznań, 2012, s. 21-31. 
starożytnych Greków ${ }^{15}$ oraz metodami stosowanymi we Francji, Niemczech i Czechach. Znał wskazówki A. Cieszkowskiego i metodę wychowawczą Fröbla.

Bojanowski stworzył syntezę myśli i praktyki pedagogicznej, począwszy od czasów Platona ${ }^{16}$, poprzez nowość wniesioną przez chrześcijaństwo i ducha ascetyzmu wieków średnich, idee filozoficzne oświecenia, poglądy utopistów, aż po współczesne mu prądy, wyrosłe na gruncie romantyzmu, idee pozytywistyczne i filozofię narodową. Przyjmując krytyczną postawę badawczą, nie podążył za żadnym skrajnym kierunkiem. Zwracał uwagę na to, że w praktyce wychowawczej, zamiast budowania na dobrych doświadczeniach starożytnych, ludzkość z przejściem do średnich i nowych wieków powzięła odwrotny kierunek - wewnętrzny. W średniowieczu, w wyższych warstwach społecznych „wychowanie dziecięce, pomijając prawidła kolejnych stopni swego naturalnego rozwinięcia, wyradzało się potwornie w przedwczesną naukowość, przybierało formę szkolnej nauki albo wraz z późniejszym spieszczeniem obyczajów przeradzało się w sztuczną układność i coraz większe upodobnienie z życiem dojrzalszym"17. Bojanowski postulował, by zniknęło z dziecięcych ochronek szkolnictwo, na które przyjdzie czas w późniejszych etapach rozwoju dziecka oraz by wychowaniem dzieci zajęły się kobiety. Wychowanie miało być „narodowe, jednakie, powszechne jak równość dziecięca, ludowa, kobieca ${ }^{18}$. Bojanowski znał także postać i poglądy J. H. Pestalozziego, który według słów Edmunda w wychowaniu dzieci widział jedyny ratunek dla upadłej ludzkości ${ }^{19}$. W swoich notatkach, dotyczących życia Tadeusza Kościuszki, wspomina o jego spotkaniu z Pestalozzim oraz tym, że wyraził pragnienie, by w Polsce zakładano instytucje dla ubogich dzieci na wzór instytutu w Yverdun ${ }^{20}$. Rezygnacja z przeładowania programu wychowawczego nauczaniem i zaangażowanie $\mathrm{w}$ proces wychowawczy kobiet $\mathrm{z}$ ich naturalną troskliwością i czułością, upodabnia pomysł na wychowanie Bojanowskiego i Pestalozziego. Wśród innych wpływów na koncepcje pedagogiczne błogosławionego z Wielkopolski wymienia się także

15 Por. M. Opiela, Integralna Pedagogika Przedszkolna w systemie wychowania Edmunda Bojanowskiego. Kontynuacja i zmiana, Lublin 2013, s. 31.

${ }_{16} \mathrm{~W}$ poglądach Platona i greckiej paidei inspirowała go, $\mathrm{z}$ jednej strony idea wczesnego wychowania dziecka w specjalnych placówkach podlegających państwu, z drugiej zaś - koncepcja systematycznej opieki wychowawczej nad małymi dziećmi w celu harmonijnego rozwoju ich osobowości, rozwoju fizycznego, moralnego i umysłowego, na podstawie specjalnie opracowanego programu i w dobrych warunkach materialnych. Zob. E. Gigilewicz, M.L. Opiela, Prace, szkice i notatki Edmunda Bojanowskiego. Inedita, T. I, Lublin 2016, s. 239, 250, 270, 273.

${ }_{17}$ M. Opiela, Integralna Pedagogika Przedszkolna..., s. 32.

${ }_{18}$ Por. M.L. Opiela, Kompendium edukacyjne..., s. 65

19 Por. M.L. Opiela, Chrystocentryzm w koncepcji wychowania integralnego wedtug błogosławionego Edmunda Bojanowskiego, materiały z sympozjum, w: Aktualność idei pedagogicznych błogosławionego Edmunda Bojanowskiego i ich implikacje katechetyczne, Poznań, 2012, s. 63-89.

${ }^{20}$ Por. E. Gigilewicz, M.L. Opiela, Prace, szkice i notatki Edmunda Bojanowskiego. Inedita, T. II, Lublin 2016, s. 94.; M. Gigilewicz, Pestalozzi, w: Encyklopedia Katolicka, dz. cyt., s. 371. 
Chowannę $\mathrm{B}$. Trentowskiego ${ }^{21}$. Z trójki omawianych $\mathrm{w}$ artykule pedagogów Trentowski zetknął się w Królewcu z Herbartem, jego twórczość nie wywarła jednak na niego większego wpływu. Pedagogika Trentowskiego usiłowała przezwyciężyć nie tylko ograniczenia germańskiej, ale i romańskiej filozofii wychowania. W ten sposób powstała w $1848 \mathrm{r}$. Chowanna (Pełen tytuł tego dzieła brzmi: Chowanna, czyli system pedagogiki narodowej jako umiejętności wychowania, nauki i oświaty, słowem wykształcenia naszej młodzieży), czyli napisana po polsku słowiańska filozofia wychowania. Tym, co upodabnia ogólny charakter myśli Trentowskiego i Herbarta jest dążenie do stworzenia systemu. Także i jego pedagogika jest filozofią stosowaną. Na tym jednak kończą się analogie $e^{22}$.

Badania źródłowe prowadzą do wyróżnienia następujących, ściśle ze sobą zintegrowanych jedenastu idei pedagogicznych bł. E. Bojanowskiego ${ }^{23}$ : wychowania fizycznego i zdrowotnego, wychowania poprzez pracę, wychowania intelektualnego aspektu osoby, wychowania społecznego, wychowania patriotycznego, wychowania rodzinnego, wychowania w kulturze regionu, wychowania estetycznego, wychowania moralnego, wychowania ku wartościom i wychowania religijnego - chrześcijańskiego. Do każdej z tych idei Bojanowski zaproponował konkretne środki wychowawcze, takie jak: dietetyka i higiena, ćwiczenia ciała, igraszki dziecięce, zabawy, gry i tańce (w wychowaniu fizycznym), powieści, opowiadania, powiastki, podania, zagadki, bajki, klechdy, legendy, pieśni (w wychowaniu umysłowym i moralnym), obrzędy i zatrudnienia (w wychowaniu obyczajowym i społecznym) ${ }^{24}$.

Już w tak naszkicowanym zarysie widzimy wyraźne wpływy koncepcji Pestalozziego „trzech sił” w sferze predyspozycji i zdolności, które należy maksymalnie i harmonijnie rozwijać. W całej koncepcji wychowawczej pobrzmiewa herbartowskie "nauczanie wychowujące”, chociaż tutaj zdecydowanie idące w kierunku budowania relacji z wychowankiem, a nie karności i przedmiotowego traktowania ucznia. Rozumienie wychowania Bojanowski wyprowadził z etymologii tego słowa. Twierdził, że: „Wychowanie jest zachowywaniem obyczajów rodzinnych - ma charakter zachowawczy tych zwyczajów, z których idą obyczaje”. Najwyższym celem wychowania jest, „aby człowiek stał się obrazem i podobieństwem Boga na ziemi" 25 . Wychowanie w wymiarze indywidualnym rozumiał Bojanowski jako umiejętne wspieranie harmonijnego, pełnego rozwoju dziecka od najwcześniejszych chwil jego życia. Zadaniem wychowawczyni było takie poznanie indywidualnych możliwości i zainteresowań dzieci, by

21 Zob. E. Gigilewicz, M.L. Opiela, Prace, szkice i notatki ..., s. 32, 38, 353, 367.

22 Por. B. Śliwerski, Pedagogika. Podstawy nauk o wychowaniu..., s. 66.

23 Por. A. Maj, Współczesny kontekst katechetyczny idei pedagogicznych...

24 Por. M.L. Opiela, Kompendium edukacyjne..., s. 187-430

25 M. Opiela, Integralna Pedagogika Przedszkolna w systemie wychowania... 
wychowywać je integralnie. Bojanowski do tego zadania przygotowywał proste, pobożne i pracowite dziewczęta $\mathrm{z}$ wiejskich rodzin. Był ich mentorem, a nawet kierownikiem duchowym. Udzielał im wskazówek dotyczących pracy z dziećmi, ale także osobistego uświęcenia.

Podstawą koncepcji pedagogicznej Bojanowskiego było liczenie się z naturą dziecka i poszanowanie jego godności ludzkiej ${ }^{26}$. W tym czasie status dziecka w rodzinie i społeczeństwie był bardzo niski i to, co dzisiaj przyjmujemy jako punkt wyjścia pedagogiki, wtedy nosiło znamiona pedagogicznej rewolucji. Poglądy dotyczące wychowania dzieci w ochronkach były dalekim echem filozofii wychowania stworzonej przez J.J. Rousseau, która znana była Bojanowskiemu ${ }^{27}$. Integralność wychowania według koncepcji Edmunda Bojanowskiego oparta była na wszechstronnym i harmonijnym rozwoju dziecka, przez uwzględnienie kolejnych etapów życia człowieka. "Jak człowiek za młodu się bawi, potem się uczy, a potem pracuje do końca dni swoich i na ostatek rachuje się ze wszystkich spraw żywota swego; tak i dzieci już w ochronie w każdym dniu tygodnia i całym roku, tym samym porządkiem wszystkie te sprawy odbywać mają"28.

Bojanowski stworzył szczegółowy program wychowawczy oparty na rytmie dziennym, tygodniowym i rocznym ${ }^{29}$. Każdy dzień w ochronce rozpoczynał się modlitwą, a następnie dzieci bawiły się pod kierunkiem siostry. Potem przychodził czas na maksymalnie półgodzinną naukę katechizmu, Biblii, czytania, pisania, liczenia, śpiewania i recytowania. Nauka odbywała się poprzez zabawę i metody dostosowane do wieku dzieci. W południe odmawiano modlitwę Anioł Pański i dzieci wracały do domów na obiad. Po powrocie i odśpiewaniu dopasowanej do danego dnia pieśni, dzieci podejmowały prace w domu i w ogrodzie (w zależności od pory roku). Wieczorem powracano do nauki liczenia, a dzień kończył się rachunkiem sumienia, przy okazji którego nagradzano i chwalono dzieci. Zakończeniem dnia była wspólna modlitwa. Każdy dzień tygodnia miał również określone treści i metody wychowawcze. I tak poniedziałek był poświęcony Opatrzności Bożej i łagodnemu przejściu od niedzielnego wypoczynku do codziennych obowiązków. Wtorek był dniem nabożeństwa do Aniołów Stróżów i rozwijania takich cech, jak troskliwość, opiekuńczość i łagodność. W środę dzieci miały szczególnie pamiętać o modlitwie za zmarłych i uczyły się patriotyzmu. Czwartek był radosnym dniem wspomnienia ustanowienia Eucharystii i uczeniem się dzielenia z innymi. Piątek to wspomnienie Męki Pańskiej i uczenie się rozumienia i przyjmowania cierpienia własnego i bliźnich.

26 Por. Tamże, s. 95n.

27 Zob. E. Gigilewicz, M.L. Opiela, Prace, szkice i notatki..., s. 239, 252.

28 Por. R. Kisiel, Błogosławiony Edmund Bojanowski..., s. 15-20.

29 Zob. E. Gigilewicz, M.L. Opiela, Prace, szkice i notatki..., s. 435-443. 
Sobota poświęcona była Najświętszej Maryi Pannie i stanowiła podsumowanie treści edukacyjnych z całego tygodnia ${ }^{30}$.

Również rok liturgiczny miał w ochronkach swoją specyficzną dynamikę. Adwent był czasem wyciszonych zabaw i przygotowania szopki bożonarodzeniowej. W okresie Bożego Narodzenia zabawy nawiązywały do lat dziecięcych Chrystusa, dzieci były uczone troski o zwierzęta i rośliny, by mogły przetrwać zimę. W Wielkim Poście siostry miały w sposób dostosowany do mentalności dziecka opowiadać Mękę Pańską i praktykowały krótkie milczenie codziennie o godzinie piętnastej. W okresie od Zmartwychwstania do Zesłania Ducha Świętego przyjmowano nowe dzieci do ochronki. Bojanowski widział w tym nawiązanie do przyjmowania do Kościoła nowo ochrzczonych. W cykl roku liturgicznego w ochronce Edmund włączał wszystkie święta maryjne, ustawiając w widocznym miejscu w ochronce figurę Matki Bożej. Szczególnie wymiar maryjny był widoczny w maju. Kolejne dni od Zesłania Ducha Świętego do Adwentu łączyły się ze żniwami i zbiorami z pól. Udziałem w procesji dzieci czciły uroczystość Bożego Ciała, a na uroczystość Wniebowzięcia NMP dzieci przygotowywały wiązanki z warzyw i zbóż, które w kościele święcono ${ }^{31}$. Koncepcję pedagogiczna Bojanowskiego można nazwać więc pedagogiką integralną. Założyciel Zgromadzenia Sióstr Służebniczek mówił o swoistej trójwymiarowości rozwoju i wychowania dziecka ${ }^{32}$. Kształcenie fizyczne, moralne i obyczajowe to kierunki, które harmonijnie pielęgnowane i „chronione” przez wychowawcę prowadzą do pełnego rozwoju osobowości człowieka.

\section{Wychowanie integralne jako ciągle aktualna propozycja}

Artykuł był próbą pokazania, że wspólne źródło, czyli pomysł na wychowanie przez pracę J.H. Pestalozziego, utworzyło dwa odmienne strumienie: wychowanie przez nauczanie J.F. Herbarta oraz wychowanie integralne E. Bojanowskiego. Po upływie 200 lat od opublikowania Pedagogiki J.F. Herbarta, mimo wielu udanych prób reformowania szkoły, myśl pedagoga z Oldenburga istotnie wpływa na kształt systemów wychowawczych. Zmieniający się w szybkim tempie świat, nowe technologie, media oprócz niezaprzeczalnych zalet, generują także nowe problemy wychowawcze, wobec których nauczanie wychowujące okazuje się być nieskutecznym. Być może propozycja wychowania integralnego autorstwa

${ }^{30}$ Por. K. Maciejewska, Wtajemniczenie w przeżywanie roku liturgicznego. Koncepcja Błogosławionego Edmunda Bojanowskiego, materiały z sympozjum, w: Aktualność idei pedagogicznych błogosławionego Edmunda Bojanowskiego i ich implikacje katechetyczne, Poznań, 2012, s. 45-52.

31 Por. R.N. Hagiel, Błogosławionego Edmunda Bojanowskiego koncepcja wtajemniczenia w przeżywanie roku liturgicznego, materiały z sympozjum: tamże, s. 53-62.

32 Por. M. L. Opiela, Kompendium edukacyjne Edmunda Bojanowskiego, dz. cyt. s. 149 
Edmunda Bojanowskiego, żyjącego 200 lat temu wielkopolskiego wychowawcy, będzie inspiracją dla współczesnych wychowawców, zmagających się z problemami kolejnego pokolenia dzieci i młodzieży ${ }^{33}$.

\section{Bibliografia}

Alana K., Johann Friedrich Herbart, http://plato.stanford.edu/entries/johann-herbart/\#BioSke, tł. wł. [dostęp: 25.11.2016].

Gara J., Specyfika polskiej recepcji twórczości Johanna Friedricha Herbarta, w: Przegląd Pedagogiczny, T. 2, 2012, s. 22-32.

Gigilewicz E., Opiela M.L. (red.), Prace, szkice i notatki Edmunda Bojanowskiego. Inedita, (red.), vol. II, Lublin 2016.

Gigilewicz E., Opiela M.L. (red.), Prace, szkice i notatki Edmunda Bojanowskiego. Inedita, (red.), vol. I, Lublin 2016.

Gigilewicz M., Pestalozzi, w: Encyklopedia Katolicka, vol. XV, kol. 371, Lublin 2011.

Hagiel R.N., Błogosławionego Edmunda Bojanowskiego koncepcja wtajemniczenia w przeżywanie roku liturgicznego, materiały z sympozjum: Aktualność idei pedagogicznych błogosławionego Edmunda Bojanowskiego i ich implikacje katechetyczne, Wydział Teologiczny Uniwersytetu Adama Mickiewicza, Poznań 2012.

Kisiel R., Błogosławiony Edmund Bojanowski i jego idea wychowania religijnego, materiały z sympozjum: Aktualność idei pedagogicznych błogosławionego Edmunda Bojanowskiego i ich implikacje katechetyczne, Wydział Teologiczny Uniwersytetu Adama Mickiewicza, Poznań 2012.

Kornacka M., Bojanowski Edmund, w: Encyklopedia Katolicka, kol. 738-739, Lublin 1976.

Kujawiński J., Ewolucja szkoły i jej współczesna wizja, Wydawnictwo Naukowe Uniwersytetu Adama Mickiewicza, Poznań 2010.

Kuhlemann G., Childhood and Youth in Zurich, http://www.en.heinrich-pestalozzi.de/biography/ childhood-and-youth-in-zurich/, tł. wł., [dostęp: 24.11.2016].

Maciejewska K., Wtajemniczenie w przeżywanie roku liturgicznego. Koncepcja Błogosławionego Edmunda Bojanowskiego, materiały z sympozjum: Aktualność idei pedagogicznych błogosławionego Edmunda Bojanowskiego i ich implikacje katechetyczne, Wydział Teologiczny Uniwersytetu Adama Mickiewicza, Poznań 2012.

Maj A., Współczesny kontekst katechetyczny idei pedagogicznych błogosławionego Edmunda Bojanowskiego, materiały z sympozjum: Aktualność idei pedagogicznych błogosławionego Edmunda Bojanowskiego i ich implikacje katechetyczne, Wydział Teologiczny Uniwersytetu Adama Mickiewicza, Poznań 2012.

Marczewski M., Herbart Johann Friedrich, w: Słownik katechetyczny, (red.) Gevaert J., Misiaszek K., Warszawa 2007.

Opiela L., Chrystocentryzm w koncepcji wychowania integralnego według błogosławionego Edmunda Bojanowskiego, materiały z sympozjum: Aktualność idei pedagogicznych błogosławionego Edmunda Bojanowskiego i ich implikacje katechetyczne, Wydział Teologiczny Uniwersytetu Adama Mickiewicza, Poznań 2012.

Opiela M., Integralna Pedagogika Przedszkolna w systemie wychowania Edmunda Bojanowskiego. Kontynuacja i zmiana, Katolicki Uniwersytet Lubelski Jana Pawła II, Wydział Nauk Społecznych, Lublin 2013.

33 Zob. J. Zjawin, Wychowanie integralne jako szansa przezwyciężenia kryzysu, w: „Katecheza. Rodzina, parafia i szkoła”, T. 8 (2010), Poznań, s. 37-43. 
Opiela M.L. (red.), Kompendium edukacyjne Edmunda Bojanowskiego, Biblioteka Katedry Pedagogiki Chrześcijańskiej KUL, Rynio A. (red.), vol. 11, Lublin 2016.

Śliwerski B., Pedagogika. Podstawy nauk o wychowaniu, Gdańsk 2014.

Walkusz J., Herbart, w: Encyklopedia Katolicka, vol. VI, kol. 738, Lublin 1993.

Zjawin J., Wychowanie integralne jako szansa przezwyciężenia kryzysu, w: Katecheza. Rodzina, parafia i szkoła, T. 8, Poznań 2010, s. 37-43.

\section{Summarium}

Artykuł ukazuje koncepcję wychowania integralnego stworzoną przez błogosławionego Edmunda Bojanowskiego na tle poglądów pedagogicznych jego epoki. Specyficzna sytuacja narodu polskiego pozostającego pod zaborami, idee pracy organicznej i pracy u podstaw, silne związki patriotyzmu z wiarą chrześcijańską - to tylko niektóre inspiracje dla programu wychowawczego, stosowanego po dziś dzień przez Siostry Służebniczki w ochronkach dla dzieci przedszkolnych. Bojanowski z jednej strony nawiązuje do koncepcji wielkich teoretyków wychowania XIX wieku, z drugiej tworzy własny, oryginalny program pedagogiczny, który poleca swoim Siostrom do szczegółowego stosowania, od czego uzależnia jego skuteczność. Ta ciągle niesłabnąca skuteczność może stać się inspiracją do rozwiązania współczesnych problemów, związanych z wychowaniem młodego pokolenia.

Słowa klucze: wychowanie, wychowanie integralne, pedagogika integralna, Bojanowski, Herbart, Pestalozzi.

The role of work and teaching in the concept of integral education of Edmund Bojanowski on the background of the European educational trends of the 19th century

\section{Summary}

The article shows the concept of integral education created by Blessed Edmund Bojanowski against the pedagogical views of his era. Ideas of organic work and work at the base, strong relationships of patriotism with Christian faith are just some of the inspirations for the education program still used today by the Sisters in their infant schools. Bojanowski, on the one hand, refers to the concept of great theoreticians of the 19th century education and, on the other, creates his own original pedagogical program, which instructs his sisters to apply in detail, thereby making his effectiveness dependent. This constant effectiveness can be an inspiration for solving contemporary problems of raising a young generation.

Keywords: upbringing, integral education, integral pedagogy, Bojanowski, Herbart, Pestalozzi. 